\title{
Assessment of Cytotoxicity on Moringa Olifera Against Ehrlich Ascites Carcinoma in Swiss Albino Mice
}

\section{Gokila Devi T ${ }^{1}$, Nagaraja Suryadevara $\mathbf{S}^{2 *}$, Gopinath L R ${ }^{1}$}

${ }^{1}$ Department of Biotechnology, Vivekanandha Educational Institutions, Tiruchengode, Namakkal, Tamilnadu, India. ${ }^{2}$ Department of Biomedical Sciences, Faculty of Medicine, MAHSA University, Malaysia.

\begin{abstract}
Objective: The present study determines the potent cytotoxic and antitumor properties of methanolic extract of Moringa oleifera leaves. Material and Method: The leaves were collected from in and around Tiruchengode of Nammakal district of Tamilnadu. The collected leaves were shade dried and powdered and the Methanolic extract was extracted using the soxhlet apparatus. In-vitro cytotoxicity study was done by Tryphan Blue Dye Exclusion method and MTT (3-(4, 5-dimethyl thiazolyl-2)-2, 5- diphenyltetrazolium bromide) assay. In short-term cytotoxicity study by Tryphan Blue Dye Exclusion method the $\mathrm{IC}_{50}$ value against EAC cell lines was found to be $163.91 \mu \mathrm{g} / \mathrm{ml}$. In Long-term cytotoxicity study by MTT assay the $\mathrm{IC}_{50}$ value against Normal Mouse Embryonic Fibroblast (NIH 3T3) was found to be $260.85 \mu \mathrm{g} / \mathrm{ml}$ for Human Cervical Cancer cells (HeLA) was $182.41 \mu \mathrm{g} / \mathrm{ml}$ for Human Laryngeal Epithelial Carcinoma (HeP-2) was 195.93. $\mu \mathrm{g} / \mathrm{ml}$ and for Human Liver Cancer cells (HepG2) was $168.61 \mu \mathrm{g} / \mathrm{ml}$. The MST of the control group was $17.33 \pm 1.53$ days, whereas it was $43.67 \pm 1.15$, $23.67 \pm 1.53$ and $33.33 \pm 1.53$ days for the groups treated with MMO (200 and $400 \mathrm{mg} / \mathrm{kg}$ ) and 5-FU respectively (0.001 \& 0.001). The increase in lifespan of Tumour-bearing mice treated with MMO and 5-FU was found to be 36. 75, 92.78 and 152.84 respectively. Result: Haematological parameters of a tumour bearing mice on the day 14 were showed significant changes when compared to normal mice. The total WBC count, protein and PCV were found to increase with a reduction in the hemoglobin content of RBC. At the same time interval, MMO ( 200 and $400 \mathrm{mg} / \mathrm{kg}$ ) treatment could change these parameters near normal. Maximum alternation occurred in the MMO treatment at the dose of $(400 \mathrm{mg} / \mathrm{kg})$. There was the significant reduction in the Tumour volume of mice treated with MMO (200 and $400 \mathrm{mg} / \mathrm{kg} / \mathrm{p}$.o.). The Tumour volume of control animals was $2.92 \pm 0.12 \mathrm{ml}$ where it was $2.55 \pm 0.11 \mathrm{ml}$ and $1.82 \pm 0.04 \mathrm{ml}$ for the groups treated with MMO $(200$ and $400 \mathrm{mg} / \mathrm{kg} / \mathrm{p} . \mathrm{o})$ respectively $(\mathrm{P}<0.01 \& 0.005)$. Conclusion: The present study provides clear evidence, that the extract of Moringa olifera shows effective cytotoxicity against Ehrlich ascites carcinoma (EAC) cells in Swiss albino mice. A further study about the active principles and mechanism of action of the Methanolic extract of Moringa oleifera at the molecular level was needed.
\end{abstract}

Keywords: Ehrlich ascites carcinoma (EAC), Human Liver Cancer cells (HepG2), Human Cervical Cancer cells (HeLA), MTT

Asian Pac J Cancer Biol, 2 (3), 57-61

Submission Date: 05/15/2017～Acceptance Date: 08/25/2017

\section{Introduction}

Development of science and technology lead to the systematic understanding of functional attributes of living organisms at macro and micro levels. This evolving knowledge of molecular biochemical changes lead to the evolution of the variety of medicines and traveled far off from natural cure and used unnatural products by neglecting the traditional healing mechanisms. But in recent years increasing realization is observed that though traditional healing mechanisms do not have systematic molecular mechanisms they were able to cure dreadful diseases like cancer. However, Indian traditional medicine is based on various systems include Ayurveda, Unani, Siddha, Yoga, and Naturopathy.

It has also been observed that more than $80 \%$ ( 3.5 to 4 billion) of the people in the developing world rely on traditional medicine for their primary health

Corresponding Author:

Dr. Nagaraja Suryadevara S

Department of Biomedical Sciences, Faculty of Medicine, MAHSA University, Malaysia.

Email: nagaraja@mahsa.edu.my 
care needs, where about $85 \%$ of traditional medicine involves the use of plant extracts (WHO). Due to the presence of active constituents such as alkaloids, flavonoids, and glycosides, known as phytochemicals and forms the basis of their healing property which is also known as phytopharmacology. The main objective of phytopharmacology is to isolate the active phytochemicals to analyze as well as characterize their pharmacological activity from the isolated compounds.

In the present world among the variety of diseases, cancer and its complications become one of the most common cause of death among the people. Among the treatments in the present world chemotherapy remains as an effective choice for the treatment of cancer but remain to be ineffective in many cases due to the severe toxicity which includes reduced immunity, suppression of bone marrow and alopecia. Gradually increasing attention on the herbal remedy for cancer therapy shows that herbal drugs provide some benefit over allopathic medicine including low toxicity. Among the different plant species Moringa species reported to have a potent anticancer activity [1-2] Moringa oleifera is an herbal drug, which is used by tribes and native medical practitioners from time immemorial to treat different kinds of diseases such as arthritis, heart disease, cancer and gastric ulcer [3-4]. However, a cytotoxicological study on animal model for this plant during cancer treatment is limited and needs extensive research Hence the present work was conducted to identify their role in cytotoxicology during cancer treatment using animal model.

\section{Materials and Methods}

\section{Ehrlich Ascites Carcinoma Cell (Mouse Tumor)}

Ehrlich ascites carcinoma (EAC) cells have been used throughout the study. The cells were obtained from the courtesy of Amala Cancer Research Center, Thrissur, Kerala, and India. EAC cells were maintained by weekly intraperitoneal inoculation of $2 \times 10^{6}$ cells/mouse.

\section{Human Tumour Cell Lines}

Human Cervical Cancer cell line (HeLA), Human Laryngeal Epithelial Carcinoma cell line (HeP-2), Human Liver Cancer cell line (HepG2) were the three human carcinoma cell lines used in the present study. The cell lines were obtained from Cancer Research Institute, Adayar, Chennai, India.

\section{Methods}

Coarsely powdered plant material was extracted with $80 \%$ methanol at room temperature for $72 \mathrm{hrs}$. The phytochemical constituents present in the sample were identified by the phytochemical tests based on the references of [5-8]. The percentage of cytotoxicity was determined by MTT assay method [9] and the $\mathrm{IC}_{50}$ value was calculated [10].

For studying the anticancer activity, the following parameters like Median survival time (MST), Hematological parameters and the Solid tumor volume were determined [11-12]. MST was calculated by using the following formula

$\%$ Increase in lifespan $=\mathrm{T}-\mathrm{C} / \mathrm{C}$ x 100

Where T- Average survival time of the test animals C- Average survival time of the control animals.

\section{Results}

The phytochemical analysis of the leaf extract showed the presence of alkaloids, carbohydrates, steroids, proteins, saponins, fixed oil and fat, tannins, phenolic compounds, flavonoids, glycosides.

In the in vitro cytotoxicity studies, the $\mathrm{IC}_{50}$ value against EAC cell lines was found to be $163.91 \mu \mathrm{g} / \mathrm{ml}$ whereas the Normal Mouse Embryonic Fibroblast, (NIH 3T3), Human Liver Cancer cell lines (HepG2), Cervical Cancer cell lines (HeLA) and Human Laryngeal Epithelial Carcinoma cell lines (HeP-2) showed 260.85,182.41, 168.61, and 195.93 respectively (Table 1 ).

In the in vivo antitumor studies the MST of the control group showed $17.33 \pm 1.53$ days, when compared with the groups treated with MMO $(200$ and $400 \mathrm{mg} / \mathrm{kg})$ was $23.67 \pm 1.53,33.33 \pm 1.53$ days. The increase in lifespan of Tumor-bearing mice treated with $\mathrm{MMO}$ and 5-FU was found to be 35.08, 91.83 and 167.94 (Table 2).

In the haematological analysis, in treated $\mathrm{MMO}$ 200 and MMO 400, the parameters like WBC, HTTP, $\mathrm{TP}$, and MID showed increased values whereas the other parameters like HB, RBC, Lym and Gran showed decreased values when compared with the control (Table 3).

The analysis of MMO on solid tumor volume showed the significant reduction in the Tumour volume of mice treated with MMO 200 and 400. The Tumour volume

Table 1. In Vitro Cytotoxicity Studies On Human Cancer Cell Lines

\begin{tabular}{lc}
\hline Cell lines used & $\mathrm{IC}_{50}(\mu \mathrm{g} / \mathrm{ml})$ \\
\hline NIH 3T3 & $260.85 \pm 6.08$ \\
HeLA & $182.41 \pm 1.85$ \\
HepG2 & $168.61 \pm 3.99$ \\
HeP2 & $195.93 \pm 2.84$ \\
EAC & $163.91 \pm 4.03$ \\
\hline
\end{tabular}

Table 2. Effect of MMO on Mean Survival Time and Increase in Life Span of EAC Tumour Bearing Mice

\begin{tabular}{lccc}
\hline Design of treatment & $\begin{array}{c}\text { MST } \\
\text { (in days) }\end{array}$ & $\begin{array}{c}\text { Increase in life } \\
\text { span T/C \% }\end{array}$ \\
\hline $\begin{array}{l}\text { Tumour Control } \\
(1 \% \text { sodium CMC) (1ml/kg/p.o) }\end{array}$ & $17.33 \pm 1.53$ & - & \\
5 -FU (200mg/kg/i.p) & $43.67 \pm 1.15$ & 152.84 & 15.95 \\
MMO 200 & $23.67 \pm 1.53$ & 36.75 & 4.84 \\
MMO 400 & $33.33 \pm 1.53$ & 92.78 & 7.98 \\
\hline
\end{tabular}

$\mathrm{n}=6$; Data were expressed as mean $\pm \mathrm{SEM}$; ${ }^{\mathrm{P}} \mathrm{P}<0.001$ when compared with Tumour Control; ${ }^{b} \mathrm{P}<0.001$ when compared with 5Fluorouracil; The data were analyzed by using one way (ANOVA) followed by Tukey Kramer multiple comparison test. 
Table 3. Effect of MMO on Haematological Parameters of EAC Tumour Bearing Mice

\begin{tabular}{lcccccccc}
\hline Design of treatment & $\mathrm{Hb}$ & $\mathrm{RBC}$ & $\mathrm{WBC}$ & $\mathrm{HCT}$ & $\mathrm{TP}$ & $\mathrm{Lym}$ & $\mathrm{MID}$ & Gran \\
\hline Normal & $1.35 \pm 13.84$ & $7.96 \pm 1.57$ & $5.98 \pm 1.51$ & $17.19 \pm 2.04$ & $5.51 \pm 1.12$ & $61.25 \pm 2.49$ & $15.90 \pm 2.65$ & $25.47 \pm 1.88$ \\
Tumour Control $(1 \%$ & & & & & & & & \\
Sodium CMC) $(1 \mathrm{ml} /$ & $1.71 \pm 7.81$ & $5.18 \pm 1.72$ & $7.88 \pm 0.99$ & $31.69 \pm 1.95$ & $14.33 \pm 2.10$ & $18.03 \pm 1.41$ & $65.71 \pm 2.44$ & $17.59 \pm 1.90$ \\
$\mathrm{~kg} / \mathrm{p} .0)$ & & & & & & & & \\
MMO 200 & $2.22 \pm 11.97$ & $5.78 \pm 1.81$ & $6.67 \pm 0.84$ & $19.96 \pm 2.10$ & $11.97 \pm 1.52$ & $47.51 \pm 1.91$ & $23.13 \pm 3.02$ & $23.92 \pm 2.48$ \\
MMO 400 & $2.06 \pm 13.84$ & $7.34 \pm 1.06$ & $5.00 \pm 0.58$ & $18.27 \pm 1.58$ & $6.79 \pm 1.11$ & $54.82 \pm 1.72$ & $21.45 \pm 2.51$ & $22.28 \pm 2.01$ \\
\hline
\end{tabular}

n, 5; Data were expressed as mean $\pm \mathrm{SEM}$; ${ }^{\mathrm{a}} \mathrm{P}<0.001 ;{ }^{\mathrm{b}} \mathrm{P}<0.01 ;{ }^{\mathrm{C}} \mathrm{P}<0.05$ when compared with Normal; ${ }^{\mathrm{d}} \mathrm{P}<0.001 ;{ }^{\mathrm{e}} \mathrm{P}<0.05$ when compared with Tumour Control; The data were analyzed by using one way (ANOVA) followed by Tukey Kramer multiple comparison test.

Table 4. Effect of MMO on Solid Tumour Volume of EAC Tumour Bearing Mice

\begin{tabular}{|c|c|c|c|c|c|c|}
\hline \multirow[t]{2}{*}{ Design of treatment } & \multicolumn{6}{|c|}{ Solid Tumour Volume (ml) } \\
\hline & 5th day & 10th day & 15th day & 20th day & 25 th day & 30th day \\
\hline Tumour Control (1\% Sodium CMC) ( $1 \mathrm{ml} / \mathrm{kg} / \mathrm{p} . \mathrm{o})$ & $0.66 \pm 0.03$ & $0.81 \pm 0.17$ & $1.33 \pm 0.23$ & $1.80 \pm 0.09$ & $1.80 \pm 0.16$ & $2.92 \pm 0.12$ \\
\hline MMO 200 & $0.56 \pm 0.03$ & $0.86 \pm 0.02$ & $0.88 \pm 0.01$ & $1.32 \pm 0.07$ & $1.67 \pm 0.05$ & $2.55 \pm 0.11$ \\
\hline MMO 400 & $0.36 \pm 0.02$ & $0.66 \pm 0.03$ & $0.77 \pm 0.02$ & $1.23 \pm 0.03$ & $1.68 \pm 0.04$ & $1.82 \pm 0.04$ \\
\hline
\end{tabular}

$\mathrm{n}, 6$; Data were expressed as mean $\pm \mathrm{SEM}$; ${ }^{\mathrm{a}} \mathrm{P}<0.01$; ${ }^{\mathrm{b}} \mathrm{P}<0.005$ when compared to that of Tumour Control; The data were analyzed by using one way (ANOVA) followed by Dunnet's test.

was $2.92 \pm 0.12 \mathrm{ml}, 2.55 \pm 0.11 \mathrm{ml}, 1.82 \pm 0.04 \mathrm{ml}$ for the control, treated MMO 200 and 400 respectively (Table 4).

\section{Discussion}

Cancer is a disease of misguided cells that have the high potential of excess proliferation without any apparent relation to the physiological demand. It is the second largest cause of death in the world. Of all the available anticancer drugs during 1940-2002, 40\% were natural products or natural product derived [13]. The greatest recent impacts of plant-derived drugs were observed in the area of anticancer research, where compounds such as taxol, vincristine, vinblastine, and camptothecin have dramatically improved the effectiveness of the chemotherapy against some of the dreadful cancers. Hence, there is great potential for the development of anticancer drugs from the essential plant kingdom. A large number of plants possessing anticancer properties have been documented [14-15. Plants belonging to the genus Moringa and several of their constituents have shown potent anticancer properties in many models based on the studies conducted throughout the world [2, 12, 16-21]. Based on these observations, in the present study, the MMT was evaluated for its in vitro cytotoxicity and in vivo antitumor properties.

The criteria for judging the value of any anticancer drug is the prolongation of lifespan, the disappearance of leukemic cells from the blood and reduction of solid tumor volume [22-23]. Transplantable tumor cells such as EAC are rapidly growing cancer cells with aggressive behavior. The tumor implantation includes a local inflammatory reaction, with increased vascular permeability, which results in an intense ascites fluid accumulation. The ascites fluid is essential for tumor growth since it constitutes a direct nutritional source for tumor cells [24-26]. Our results showed an increase in lifespan accompanied by a reduction in $\mathrm{WBC}$ count in MMT treated mice. The plant extract also inhibits the accumulation of ascites fluid in the peritoneal cavity of the tumor-bearing animals. This result clearly demonstrates the antitumor effect of MMT on EAC tumor cells.

The most common problem encountered in cancer chemotherapy is myelosuppression and anemia [27-28]. Anemia is found frequently in cancer patients. Similar results were observed in the present study in animals of the EAC tumor control group. This is mainly due to the reduction in $\mathrm{RBC}$ or hemoglobin production and this may occur either due to the iron deficiency or to hemolytic conditions [29-30]. Treatment with MMT brought back the hemoglobin content, RBC and WBC counts closer to normal range. This indicates that the extract has a protective effect on the hematopoietic system.

In EAC tumor-bearing animals, there was a regular and rapid increase in ascites fluid volume [24]. MMO treatment decreases the volume of the solid tumor and increases the lifespan. Hence it may conclude that MMO arrests the tumor cell growth, by a direct cytotoxic effect or by decreasing the nutritional fluid volume. The present study revealed that the extract was cytotoxic towards EAC cell lines and it was also found to be potent cytotoxic against human cancer cell lines.

The cytotoxic effect of the extract was confirmed by the in vivo cytotoxic assay methods against animal cancer cell lines and human cancer cell lines. The extract exhibit an effective cytotoxicity against all the tested cancer cell lines. At the same time, the $\mathrm{IC}_{50}$ for the normal cell lines were found to be higher while compared to cancer cell lines, that indicates the extract had a cytotoxic effect against the cancer cell lines.

A preliminary phytochemical study indicates the presence of flavonoids, saponins, tannins and phenols in MMO and these compounds are known to have effective antitumor properties [31]. The extract of Moringa olifera is rich in flavonoids and saponins. It was reported that 
flavonoids have been found to possess antimutagenic and antimalignant effect [32-33]. In addition, they have a chemopreventive role in cancer through their effects on signal transduction in cell proliferation and inhibition of neovascularization [34-35]. Saponins have found to be a beneficial target on inhibition of tumor angiogenesis via suppressing its inducer in the epithelial cells of blood vessels, by adhering the metastasis of tumor cells. They also exhibit the antitumor effect through cell cycle arrest and apoptosis [36]. Antitumor and cytotoxic properties of the extract may be due to these phytochemical constituents. Thus the present study provides clear evidence, that the extract of Moringa olifera shows effective cytotoxicity against Ehrlich ascites carcinoma (EAC) cells in Swiss albino mice.

\section{References}

1. Anwar F, Latif S, Ashraf M, Gilani AH. Moringa oleifera: a food plant with multiple medicinal uses. Phytotherapy research : PTR. 2007;21(1):17-25.

2. Purwall L PA, Jain UK .,. In vivo anticancer activity of the leaves and fruits of Moringa oleifera on mouse. Pharmacologyonline 2010.; ; : :655-65.

3. Fakurazi S SS, ArulselvanP,. . Moringa oleifera hydroethanolic extracts effecively alleviateacetaminophen-induced hepatotoxicity in experimental rats through their antioxidant nature. Int. . J of pharma tech res 2012;17::8334-50.

4. Zohara Y, Bachrach., . Contribution of selected medicinal plants for cancer prevention and therapy. . Scientific Journal of the Faculty of Medicine. 2012.;29((3):):117-23.

5. Basset J D, Jeffery JH, Mendham J,. Vogel's Text Book of Quantitative Inorganic Analysis. ELBS - Longman, Essex, UK. Edn. . 1985. ;4: :196.

6. Hebert E, Brain. and Ellery, W., Kenneth. Text Book of Practical Pharmacognosy. . Baillere, London 1984.;4: :363-8.

7. Harbourne JB. Phytochemical Methods- A Guide to Modern Techniques of Plant Analysis. . Chapman and Hall, London Edn. 1984.; 2: :4-120.

8. Kokate CK PA, Gokhale SB,. . Hematologic complications of cancer chemotherapy. Pharmacognosy. . Nirali Prakasan, Pune 1990. :123-8.

9. Sunila ES, Kuttan G. Immunomodulatory and antitumor activity of Piper longum Linn. and piperine. Journal of ethnopharmacology. 2004;90(2-3):339-46.

10. Vijayan P, Vinod Kumar S, Dhanaraj SA, Mukherjee PK, Suresh B. In vitro cytotoxicity and antitumour properties of Hypericum mysorense and Hypericum patulum. Phytotherapy research : PTR. 2003;17(8):952-6.

11. Ramnath V Gk, Ramadasan kuttan., Antitumor effect of abrin on transplanted tumors in mice. Indian J. Physiol Pharmacol 2002. ;46: :69-77.

12. Rajkapoor B MN, Lalitha K, Krishna DR,. Cytotoxic activity of flavone glycoside from the stem of Indigofera aspalathoides Vahl. 2007. . J Nat Med.61: :80-3.

13. Nidhi Agarwal. Natural herbs as anticancer drugs. Int. JPharmTech 2012.;4: :1142- 53.

14. Sumitra Chanda KN. In vitro and in vivo Methods for Anticancer Activity Evaluation and Some Indian Medicinal Plants Possessing Anticancer Properties: . An Overview. 2013. ;2 : : :140-52.

15. Picheswararao Polu UN, Saleemulla Khan.,. Herbal medicinal plants as an anticancer agent. Annals of
Phytomedicine 2015,;4((1): ):37-45.

16. Sathya TN. MoL. leaves prevent Cyclophosphamideinduced micronucleus and DNA damage in mice. Int. Jou. . of Phytomedicine. 2010.;2:: 147-54.

17. Han R. Highlight on the studies of anticancer drugs derived from plants in China. Stem cells (Dayton, Ohio). 1994;12(1):53-63.

18. Ali NA, Julich WD, Kusnick C, Lindequist U. Screening of Yemeni medicinal plants for antibacterial and cytotoxic activities. Journal of ethnopharmacology. 2001;74(2):173-9.

19. Rajkapoor B JB, Murugesh., . Antitumor activity of Indigofera aspalathoides on Ehrlich ascites carcinoma in mice. Indian J Pharmacol. 2004.;36: :38-40.

20. Rajkapoor B MN, Chodon D, Sakthisekaran D.,. Chemoprevention of N-Nitrosodiethylamine induced phenobarbitol promoted liver tumors in rats by extract of Indigofera aspalathoides. . Biol Pharm Bull. 2005;; 28 : :364-6.

21. Alex D, Lam IK, Lin Z, Lee SM. Indirubin shows antiangiogenic activity in an in vivo zebrafish model and an in vitro HUVEC model. Journal of ethnopharmacology. 2010;131(2):242-7.

22. Eman Noaman Nf, Raafat Yousri,. Evaluation of the antitumour and radiosynthestizing activity of a novel quinoline derivative as a histone deacetylase inhibitor. . J of cancer theraphy,. 2011. ;2: :567-78.

23. Meenakshi VK PM, Senthamarai S, Gomathy S, Chamundeswari KP,. Antitumor and Immunomodulatory Activity of Phallusia nigra Savigny, 1816 Against Ehrlich Ascites Carcinoma. Res. Jou. Pharm. Sci. . 2012.;1((2), ):7-12. .

24. Shimizu M AC, Taniguchi T, Murayama T, . Expression of cytosolic phospholipase $\mathrm{A} 2 \alpha$ in murine $\mathrm{C} 12$ cells, a variant of L929 cells, induces arachidonic acid release in response to phorbol myristate acetate and $\mathrm{Ca} 2++$ ionophores, but not to tumor necrosis factor- $\alpha$. . J Pharmacol Sci 2004. ;96: :324-32.

25. Segura JA BL, Marquez J.,. Ehrlich ascites tumor unbalances splenic cell population and reduces responsiveness of $\mathrm{T}$ cells to Staphylococcus aureus enterotoxin B stimulation. . Immunol Lett. 2000.;74: :111-15.

26. Fecchio D, Sirois P, Russo M, Jancar S. Studies on inflammatory response induced by Ehrlich tumor in mice peritoneal cavity. Inflammation. 1990;14(1):125-32.

27. Marklund S, Marklund G. Involvement of the superoxide anion radical in the autoxidation of pyrogallol and a convenient assay for superoxide dismutase. European journal of biochemistry. 1974;47(3):469-74.

28. Price VE, Greenfield RE. Anemia in cancer. Advances in cancer research. 1958;5:199-290.

29. De Vita VT HS, Rosenburg SA,. Cancer: Principle and practice of oncology. 4th ed. J.B.Lippincott company. . Philadelphia 1993.: 72-80.

30. Hoagland HC. Hematologic complications of cancer chemotherapy. Seminars in oncology. 1982;9(1):95-102.

31. Kintzios SE. Terrestrial plant derived anticancer agents and plant species used in anticancer research. . Critic Rev Plant Sci 2006.; 25: :79-113.

32. Hirano T OK, Akiba M,. Antiproliferative effects of synthetic and naturally occurring flavonoids on tumor cells of human breast carcinoma cell line, ZR-75-1. Res Commun Chem Pathol Pharmacol 1989.; 64: :69-78.

33. Brown JP. A review of the genetic effect of naturally occurring flavonoids, anthraquinones and related compounds. . Mutat Res 1980. ;75: :243-7.

34. Fotsis T, Pepper MS, Aktas E, Breit S, Rasku S, Adlercreutz 
$\mathrm{H}$, et al. Flavonoids, dietary-derived inhibitors of cell proliferation and in vitro angiogenesis. Cancer research. 1997;57(14):2916-21.

35. Weber G, Shen F, Prajda N, Yeh YA, Yang H, Herenyiova $\mathrm{M}$, et al. Increased signal transduction activity and downregulation in human cancer cells. Anticancer research. 1996;16(6a):3271-82.

36. Man S, Gao W, Zhang Y, Huang L, Liu C. Chemical study and medical application of saponins as anti-cancer agents. Fitoterapia. 2010;81(7):703-14.

\section{(ब) $(\Theta$}

This work is licensed under a Creative Commons AttributionNon Commercial 4.0 International License. 